\title{
Correction to: Studying of the interaction between peat humic acids and metazachlor using spectroscopy methods
}

\author{
Romualda Bejger $^{1}$ (D) $\cdot$ Lilla Mielnik ${ }^{1} \cdot$ Małgorzata Włodarczyk $^{2} \cdot$ Paweł Nicia $^{3}$
}

Published online: 30 August 2018

(C) The Author(s) 2018

Correction to: Journal of Soils and Sediments (2018) 18:2675-2681 https://doi.org/10.1007/s11368-018-1917-3

The article "Studying of the interaction between peat humic acids and metazachlor using spectroscopy methods", written by Romualda Bejger, Lilla Mielnik, Małgorzata Włodarczyk, and Paweł Nicia was originally published electronically on 16 January 2018 with incorrect copyright line in the publisher's internet portal (currently SpringerLink). The copyright line of the article should be "(C) The Author(s) 2018".

Open Access This article is distributed under the terms of the Creative Commons Attribution 4.0 International License (http:// creativecommons.org/licenses/by/4.0/), which permits unrestricted use, distribution, and reproduction in any medium, provided you give appropriate credit to the original author(s) and the source, provide a link to the Creative Commons license, and indicate if changes were made.

The online version of the original article can be found at https://doi.org/ $10.1007 / \mathrm{s} 11368-018-1917-3$

Romualda Bejger

Romualda.Bejger@zut.edu.pl

1 Department of Physics and Agrophysics, West Pomeranian University of Technology in Szczecin, ul. Papieża Jana Pawła IV/3, 71-459 Szczecin, Poland

2 Department of Chemistry, Microbiology and Biotechnology of Environment, West Pomeranian University of Technology in Szczecin, ul. Słowackiego 17, 71-434 Szczecin, Poland

3 Department of Soil Science and Soil Protection, University of Agriculture in Krakow, al. Mickiewicza 21, 31-120 Krakow, Poland 